\title{
SELECTED SOCIAL AND ECONOMIC ISSUES CONCERNING THE FINANCIAL CRISIS OF 1997-1998 IN SOUTH KoREA
}

\begin{abstract}
From the early 1960s until the crisis of 1997-1998, Korea's economic growth has been the result of an accumulation of exceptional capital mainly driven by a financial system dominated by the banking sector and tightly controlled by the government. The financial crisis of 1998 reduced the pace of the growth of the South Korean economy. Nevertheless, due to its own approach, the Korean economy faced successfully with this economic challenge. Some entities also became richer due to the crisis.

KEYWORDS: bankruptcy, capital flows, capital controls, chaebol, financial crisis, South Korea.

\section{Aim OF THE ARTICLE}

The purpose of this paper is to explain the successful strategy of overcoming financial breakdown in the case study of South Korea, taking in account the nature of the Korean society. The aim of the article is to verify the hypothesis that South Korea used its own model in order to face with the crisis. A document analysis method is applied to present essential indicators such as exchange rates and financial debts. The article analyses also the social factor, as a driver of the Korean strategy toward the economic crisis. The paper will also discuss what led to the financial crisis in South Korea.
\end{abstract}




\section{METHODOLOGY}

For the preparation of the article, the author used secondary data. Data were extirpated from secondary sources. Secondary data collection is based on internal and external data. Internal data are including sales data, financial data, operations-related data, etc. Secondary data research represents a study that uses existing data on a certain research subject from government statistics, published market research reports from different organizations, such as the IMF. The data produced from the various sources are assembled into the current article.

\section{THE BEGINNING OF THE CRISIS}

The Asian debt crisis in South Korea began on November 21, 1997, when South Korea became the object of an International Monetary Fund (IMF) bailout due to the lack of U.S. dollars with which to repay debts to foreign financial institutions. (Song, 2006, p. 40).

According to World Bank Data, the average revenue per capita in South Korea has an average annual growth percentage of $9.04 \%$ for the period 1971-1998. This economic success was due to some internal (the hardworking nature of the South Korean society), and external reasons (such as the financial support of the United States) and a specific management system (Levi, p. 160). Nevertheless, at the end of the year 1997, South Korea had to face with a crisis spreading all over Asia. Firstly, before 1997, countries such as Taiwan, and Singapore were concerned. Secondly, the crisis moved to HongKong and South Korea. The country was hit by a currency banking crisis that left it no option but to seek official assistance from the IMF (International Monetary Fund), an institution which received the best evaluation as an agency fostering recovery from the crisis (Hayo, 2005, p. 6). As a consequence, in November 1997, the Korean Won lost 50\% of its value toward the USD.

Two categories of problems were important in the determination of the crisis. First in Korea, an important problem in its financial system was the quantity on non-performing loans which sowed doubts about the credit-issue of borrowers and effectively undermined the confidence in the currencies. Secondly, an unhedged exposure to short-term foreign currencies debt created a spiral of depreciation and deepened the insolvency of Korea. This 
weakness is problematic for South Korea in the context of a high-debt equity ratio characterizing Korean corporations (Boorman, 2000, p. 5) in spite of the large flow of private inflows of capital (Winters, 1999, p. 80). This highdebt equity ratio was based on the Policy Loan of the South Korean state. For instance, a company investing in a crucial sector of the sector needed to provide only $20 \%$ of funds for the project, $80 \%$ was cofinanced by the government of financial institutions (Lautier, 1999, p. 753). This financial model set up the ground of the Korean growth based on investments.

\section{THE SOLUTION TO THE CRISIS}

At the difference of other Asian countries, the growth in South Korea was based upon the financement of its chaebols. In Japan and on the island of Taiwan, much more companies were created and therefore, the growth was not fully connected to the government, which was involved in the financement of large companies (Lautier, 1999, p. 754). The financement is also based on a deep interconnection with financial institutions financing credits through massive savings of the population due to the important economic growth of Asian countries. Empirical work on saving in Asian countries has found a strong relation between saving rates and economic growth. (Faruqee, 1998, p 198).

Thanks to the help of the IMF, but also including other multilateral institutions, Korea was able to avoid the worst possible scenario, related to a sovereign default. Later, South Korea has implemented many institutional and policy reforms not only in line with its agreement with the IMF but also on its own judgment as it will be described later in the article. The economy shows a quick recovery of the GDP growth rate, while employment growth has been sluggish. (Lee, 2002, p. 3)

Nevertheless, the inability of the IMF to control the Korean Won has forced the USA to play a political role in forcing foreign banks to halt their capital withdrawals from South Korea. As a result, Korea today is regarded by many as a country that has gone far toward strengthening its financial sector through a deep cooperation with the USA. Furthermore, due to this financial crisis, the demand on raw materials of Asian countries decreased and led to a decrease of raw materials prices, such as the Brent. South Korea, which has 
no oil reserves (Masih, 2001, p. 978), is obliged to import all of it, making it the fourth largest market in the world, with an estimated oil bill of 16 billion euros for 2002. 75\% of its oil comes directly from the Middle East (Kihwan, K., 2006, p. 34)

Globally speaking, the crisis led also to a down in Asian exports which constituted in reality a paradox. The devaluation of Asian currencies shall have led an increase of the production in these countries. However, due to a lack of liquidity, that was impossible for Asian countries to boost their production. In the case of South Korea, this led an outflow of capitals (around USD $20 \mathrm{bln}$ ), to the bankruptcy of companies, such as Kia Motors or the Daewoo Group.

The Korean government's response to the crisis was very fast. The real bankruptcy situation of the country offered them an opportunity to intensify the inevitable structural reforms, giving special power to the head of state (Economie, 2002, p. 5). This policy presents itself as a mixture of direct state intervention in the industrial fabric (the so-called "Big Deal" of President Kim Dae-jung, head-of-state for the period 1998-2002) and a sustained liberal credo. The reforms were led by the higher administration which takes into the account not only the demands of the foreign investors but also the aspirations of the civil society tired of the weight of the "chaebols" and their failure. The government of Kim Dae-jung accordingly began to establish policy measures stimulating the research activities of university academics. The 'Brain Korea 21' project (hereafter, BK21) can be considered as the main government incentive during its term (Park, 2006, p. 12).

\section{THE CHAEBOL MODEL AND THEIR FAILURE}

The crisis hit the main South Korean companies: the chaebols. South Korea, following the Japanese developmental model, achieved rapid industrialization by establishing "national champions" based on government control over and allocation of financial resources including foreign capital. As a consequence, South Korea has a high level of industrial concentration and an economy dominated by chaebols (Heo, 2003, p. 688).

The chaebols (재벌) are the large, conglomerate family-controlled societies of South Korea characterized by close ties to government agencies. 
There were family owned businesses in Korea in the period before 1961 but the particular state-corporation alliance occurred with the Park Chung-hee regime (1961-1979). The Park modeled this arrangement on the zaibatsu system that developed in Japan during the Meiji era. There were significant differences between zaibatsu and chaebol, the most significant of which was the source of capital. The zaibatsu, coming from Japan, were organized around a bank for their source of capital. The chaebol on the other hand were banned from owning a bank. The Park regime nationalized South Korea's banks and could channel scarce capital to industries and corporations it saw as needed to achieve national goals. The government-favored chaebol had special privileges and grew tall. Prior to the 1997 crisis, the only concern of South Korean banks were to fund the chaebols. These industrial giants like Hyundai, Daewoo or LG are replicas of Japanese zaibatsus. The risk assessment was non-existent and individuals without collateral could not borrow. This gave the impression of economic success for the chaebols that was not always valid. In some cases the chaebols did not grow because they were profitable but simply because they could borrow large funds. When the international economy took a decrease, these debt-ridden businesses were in trouble. In 1999 a quarter of manufacturers in South Korea did not earn enough to meet the required payments for their debt, and then they didn't fulfill their Interest Coverage Ratio.

Since the beginning of the crisis, the project suspensions and the cuts in investment budgets have followed one another. The conglomerate Hyundai announced a 30\% decline in its investments in 1998. Same type of decisions on the part of the leaders of Samsung (the second group of the country), which, in 1997, realized USD 52bn of figure of business. The group, which was preparing to produce its first automobiles in March 1997, said it was postponing the expansion of its new plant capacity, saving USD 1.2bn. In total, the group's investments fell this year by $30 \%$. Daewoo was squeezing its investments of USD 2 bn in three factories in France and size in salaries and manpower. And, as at Hyundai, Samsung's executive salaries were cut by $10 \%$, and end-ofyear bonuses removed. Due to cuts in capital expenditures, Hyundai Motor, which has a combined production capacity of 1.8 million vehicles, sold only 1.24 million in 1998. This slimming cure dictated by the crisis was not to be 
enough to put back the chaebols. It remains to attack their foundations, largely responsible for the South Korean financial crisis. Namely: unbearable debt ratios (the debt-to-equity ratio of the first thirty groups reaches 4.5 ), and a total lack of financial transparency, accompanied by a system of cross-guarantees between affiliates of groups that threatens the entire economy.

\section{THE SUPPORT OF THE IMF}

The South Korean state faced with a spectacular debt (USD 150bn), a currency that has lost nearly half of its value, put on the diet by the IMF, South Korea sinks into the recession. Struck hard by the rise in interest rates (which oscillate between 20 and 30\%), many companies were asphyxiated: 3,000 bankruptcies in December 1997, more than 50,000 took place in 1998. Far from being spared, the "chaebols", huge conglomerates that account for two-thirds of the country's GNP, and whose business extends from electronic chips to shipbuilding, via automobiles or insurance, eight of them have already gone bankrupt, including the builder Kia (third in the country), last July, the group Halla (construction), or Hanbo (iron and steel industry). The situation was mastered thanks to the intervention of international organizations, such as the IMF, which led to recapitalizations, but also to the sacking of thousands of people, for instance one thirds of employees of the Banking sector were demoted from their positions.

Title. 1

Inflation in South Korea (1998-2016)

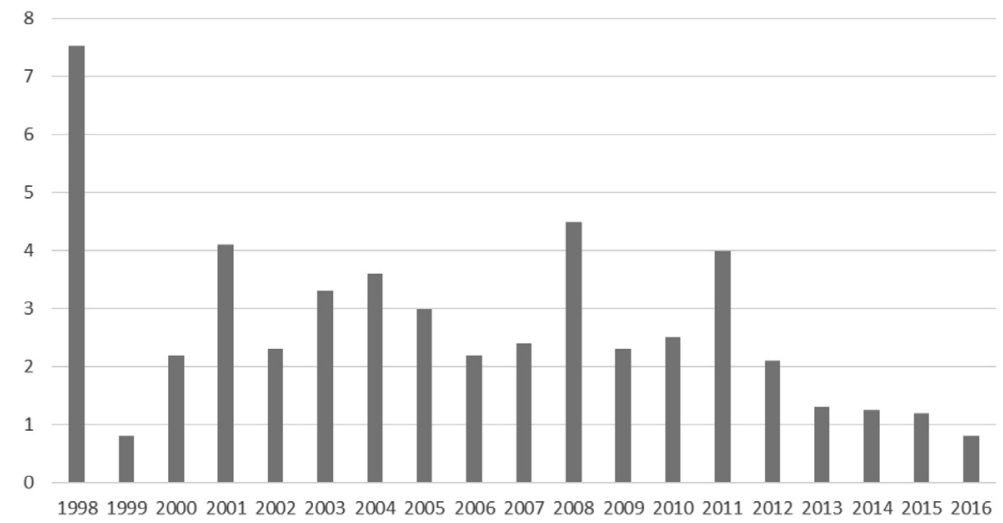


South Korea received a loan of USD 60bn by the IMF, restructured 12 of the 32 largest banks in South Korea (Agosin, 2001, p. 3).. The whole which helped the South Korean economy reducing its debt. The whole is confirmed by the importance of corporate governance in mitigating such expropriation incentives, and provide important implications for the role of corporate governance during an economic shock (Kang, 2010, p. 1)

Table 1.

Korea’s debt (1994-2000)

\begin{tabular}{|c|c|c|c|c|c|c|}
\hline \multicolumn{7}{|c|}{ (Unit: US \$, billion) } \\
\hline 1994 & 1995 & 1996 & 1997 & 1998 & 1999 & 2000 \\
\hline \multicolumn{7}{|c|}{ Total External Debt } \\
\hline 89,9 & 119,8 & 157,4 & 174,3 & 163,9 & 153 & 148,4 \\
\hline \multicolumn{7}{|c|}{ Short-term debts } \\
\hline 38,5 & 54,9 & 75,9 & 63,8 & 39 & 42,5 & 49,4 \\
\hline \multicolumn{7}{|c|}{ Long-term debts } \\
\hline 51,4 & 64,9 & 81,5 & 110,5 & 124,9 & 110,5 & 99 \\
\hline \multicolumn{7}{|c|}{ Foreign currency } \\
\hline 89,5 & 119,4 & 156,9 & 173,9 & 162,7 & 149,9 & 144 \\
\hline \multicolumn{7}{|c|}{ Korean won } \\
\hline 0,3 & 0,4 & 0,4 & 0,3 & 1,1 & 3 & 4,4 \\
\hline \multicolumn{7}{|c|}{ Banking Sector } \\
\hline 48,4 & 72 & 99,4 & 91 & 72,5 & 67,7 & 61,8 \\
\hline \multicolumn{7}{|c|}{ Short-term debts } \\
\hline 29,8 & 44,3 & 61,1 & 49,2 & 31,1 & 33,8 & 37,7 \\
\hline \multicolumn{7}{|c|}{ Long-term debts } \\
\hline 18,6 & 27,7 & 38,3 & 41,8 & 41,4 & 33,9 & 24,1 \\
\hline
\end{tabular}


Table 2 .

Unemployment rate of the Korean Labor Market

\begin{tabular}{|c|c|}
\hline Year & $\begin{array}{l}\text { Unemployment rate } \\
\text { (in \%) }\end{array}$ \\
\hline 1995 & 2,1 \\
\hline 1996 & 2 \\
\hline 1997 & 2,6 \\
\hline 1998 & 7 \\
\hline 1999 & 7,6 \\
\hline 2000 & 4,1 \\
\hline 2001 & 3,8 \\
\hline 2002 & 3,1 \\
\hline 2003 & 3,4 \\
\hline 2004 & 3,5 \\
\hline 2005 & 3,5 \\
\hline 2006 & 3,3 \\
\hline 2007 & 3 \\
\hline 2008 & 3,2 \\
\hline 2009 & 3,6 \\
\hline 2010 & 3,7 \\
\hline 2011 & 3,4 \\
\hline 2012 & 3,2 \\
\hline 2013 & 3,1 \\
\hline 2014 & 3,5 \\
\hline 2015 & 3,6 \\
\hline 2016 & 3,7 \\
\hline 2017 & 3,7 \\
\hline
\end{tabular}

Source: National Statistics Office, Economically Active Population Survey, 2017. 
Table 3.

Exchange Rate Losses in South Korea, May 1997 to June 1998

\begin{tabular}{|c|c|}
\hline Exchange rate per \$. May '97 & $\mathbf{8 9 2}$ \\
\hline Exchange rate per \$. June 98 & 1400 \\
\hline Variation & $-36 \%$ \\
\hline
\end{tabular}

Social issues

At the difference of crisis in other countries, the population actively participated in the development of a solution through several channels. First, by saving more, secondly by increasing the productivity, and the whole in a framework of a global world weak demand. People were also urged to donate foreign currencies to the government. This behavior is due to typical confucianist values, the root of the Korean culture and civilization. This was also partially due to the negative feeling toward the IMF (Song, 2006, p. 40).

The first of these concepts is collectivism (jipsanjuoe - 집 산주의), which underlines the interdependence of humans in the quest of the harmony, and consequently is a tool for reaching the harmony. In others words (and through a wide simplification), it means that people exist through, and are defined by its relations with others. The harmony can be defined as the national order, or a parameter which describes how human beings ought to act. In order to maintain relationships between humans and to reach the harmony, the following elements are used: the confidence, the loyalty (jongsonghaneun - 총송한은) toward the prince (hwangja - 황자) and the filial piety (hyo - 효) toward the elders. These relationships are structured hierarchically.

Collectivism is present on almost each level of the Korean Society and impregnates the rules of this society. According to Anna Wasiela, one of the most popular mottos in Korea is We are one family (urineun han kajok) (Wasiela, 2010, p. 152). This kind of expression is used not only in companies but also in public institutions, in political parties etc. The Korean uri means "our" which is much more used in the Korean language that the western mine. The collectivism is also influencing the way of functioning of Korean companies. As far as a CEO has a large network (the Chinese guanxi 系) in 
South Korea, he will establish his budget and his sales in accordance with his network instead of taking in account the opportunities which may exist in geographical points which are out of his network. Therefore, the size of his network is considered as a key-parameter of success. The collectivism may also result from the homogeneity of the population which considers itself as a whole and is also due to the nature of the Korean society considered as agrarian characterized by dependent views (Bae, 2012, p. 48). This collectivism may be a driver of the behavior of the Korean population toward the financial crisis. The population was highly involved in the resolution of the crisis.

Collectivism is also visible through the Big Deal of Kim Dae-jung. The South Korean president expanded government funding for NGOs and nonprofit organizations (NPOs) and elicited their participation in sharing the responsibility for managing social issues to help unemployed and homeless people (Song, 2006, p. 42).

Nevertheless, the negative social consequences cannot be hidden. The unemployment rate was of 2,6\% in 1997 (Kim, 2010, p. 7) and 7,6\% in 1999 in South Korea. The number of suicides was increased by $50 \%$ between 1996 and 1997. The xenophobic nature of the Korean society is also underlined by the fact that the Chinese community in South Korea is considered as the one which is responsible of the crisis (Haggard, 2000, p. 17).

\section{THE FINANCIAL RESTRUCTURATION AFTER THE CRISIS}

The financial restructuration of South Korean companies was very wide and related to companies such as banks, insurance companies, investment funds, leasing companies, mutual funds, and securities companies. The KB21 plan was also an important element of the South Korean recovery.

South Korean authorities have taken a number of extraordinary actions to stabilize their financial systems, through the application of a policy mix covering two issues: financial and labor markets. They include setting out temporary welfare programs for a growing number of unemployed persons people, large-scale capital injections with public funds, temporary bank nationalizations, and government bank debt guarantees, as well as massive liquidity provisioning by central banks. 
Regarding other countries, the East Asian countries suffered deep recessions in 1998, after decades of sustained annual GDP growth of around 8 percent. Indonesia exhibited a 13 percent recession, similar to the spectacular drop of Chilean GDP during the 1982 recession. Korea, Malaysia, and Thailand recorded reductions of 7 to 10 percent (Agosin, 2001, p. 19), but they were no credit contraction during the first half of 1998 (Borensztein, 2002, p. 13).

In this regard, it is important to recognize that the financial crisis did not incur economic loss in everyone's life. The effect of the financial crisis has been uneven. Those who had financial resources or extra properties took advantage of the credit-scarce situation to increase their fortunes, while many others suffered layoffs, bankruptcies (Koo, 2007, p. 10).

\section{Conclusion}

As the global economy recovered in 2000, the Korean economy started to rebound rapidly from the recession of 1998 . However, the economic recovery made it difficult to evaluate the influence of international programs on the labor market. Nevertheless, the steep reduction of unemployment rate (from $7.0 \%$ in 1998 to $3.8 \%$ in 2001) shows that the policy mix of the government helped to overcome mass unemployment (Kim, 2010, p. 7).

Interestingly, at the beginning of the 2008 global financial crisis, some economists warned of the possibility of more significant damage on the Korean economy and the labor market compared to that in the 1998 crisis. This was also due to the implication of the Korean society, a driver which is lacking in Western countries during economic crises.

\section{References:}

Agosin, M. R. (2001). Korea and Taiwan in the financial crisis. En: Financial crises in" successful" emerging economies-Washington, DC: Brookings Institution Press/ECLAC, 2001-p. 38-64. ISBN 0815702116.

Bae, J., Rowley, C., \& Sohn, T. W. (Eds.). (2012). Managing Korean business: Organization, culture, human resources and change. Routledge. ISBN 9780714652399.

Boorman, J., Lane, T., Schulze-Ghattas, M., Bulir, A., Ghosh, A. R., Hamann, J., ... \& Phillips, S. (2000, December). Managing financial crises: the experience in East Asia. Carnegie-Rochester Conference Series on Public Policy (Vol. 53, No. 1, pp. 1-67). North-Holland. ISSN 0304-3932. 
Borensztein, E., \& Lee, J. W. (2002). Financial crisis and credit crunch in Korea: evidence from firm-level data. Journal of Monetary Economics, 49(4), 853-875. ISSN 0304-3932.

Economie et Culture: le cas de la Coree du Sud, Compte rendu du deplacement d'une delegation du groupe senatorial d'amitie France-Coree du Sud, 8 mars-15 mars 2004.

Faruqee, H., \& Husain, A. M. (1998). Saving Trends in Southeast Asia: A Cross-JEST KWADRACIK -Country Analysis. Asian Economic Journal 12(3), 195-217. ISSN 1467-8381. PRoszE

Haggard, S. (2000). The political economy of the Asian financial crisis. Peterson Insti- $3 \mathrm{x}$ tute. ISBN 0881322830.

Hayo, B. (2005). Mass attitudes toward financial crisis and economic reform in Korea. Socio-Economic Review, 3(3), 491-515. ISSN 14751461.

Kihwan, K. (2006, July). The 1997-98 Korean financial crisis: Causes, policy response, and lessons. In IMF Seminar on Crisis Prevention in Emerging Markets.

Kim, S. T. (2010). Korea's unemployment insurance in the 1998 Asian financial crisis and adjustments in the 2008 global financial crisis.

Koo, H. (2007). The changing faces of inequality in South Korea in the age of globalization. Korean Studies, 31(1), 1-18.

Korean Statistical Information Service- Economically Active Population Survey

Lautier, M. (1999). Les paradoxes des restructurations industrielles en Corée du Sud. Revue Tiers Monde, 751-774. ISSN 1293-8882.

Lee, Jong-Wha et Rhee, Changyong. Macroeconomic Impacts of the Korean Financial Crisis: Comparison with the Cross-country Patterns. The World Economy, 2002, vol. 25, no 4, p. 539-562. ISSN 0378-5920.

Levi N., Wspótczesne podejście do analizy Geerta Hofstede’a w zakresie zarządzania przedsiębiorstwami koreańskimi oraz przestrzegania w nich zasad konfucjańskich, Sprawy Polityczne, 1(46), 2016. ISSN 1507-6881.

Masih, R., Peters, S., \& De Mello, L. (2011). Oil price volatility and stock price fluctuations in an emerging market: evidence from South Korea. Energy Economics, 33(5), 975-986. ISSN 0140-9883,

Maull, H. W. (1999). Crisis in Asia: Origins and Implications. Internationale Politik und Gesellschaft, 56-66. ISSN 0535-4129.

Park, H. W., \& Leydesdorff, L. (2010). Longitudinal trends in networks of university-industry-government relations in South Korea: The role of programmatic incentives. Research policy, 39(5), 640-649. ISSN 0048-7333. 
Song, J. (2006). Family breakdown and invisible homeless women: Neoliberal governance during the Asian debt crisis in South Korea, 1997-2001. positions: east asia cultures critique, 14(1), 37-65.

South Korea GDP Annual Growth Rate, Trading Economics, http://www.tradingeconomics.com/south-korea/gdp-growth-annual

Wasiela, A. (2010). Korean work ethics-modern but still Confucian. Asia \& Pacific Studies, 7, 139-158.

Winters, J. A. (1999). The determinant of financial crisis in Asia. The Politics of the Asian Economic Crisis, 79-97. 
